\title{
Impact of FDI in Retailing: An Empirical Analysis on Perception of Unemployed Youth on Employment Opportunities in India
}

\author{
Desti Kannaiah $^{1} \&$ V. Selvam ${ }^{2}$ \\ ${ }^{1}$ Faculty, School of Business, James Cook University, Singapore \\ ${ }^{2}$ Professor of Commerce, SSL, VIT University, Tamil Nadu, India \\ Correspondence: Desti Kannaiah, Faculty, School of Business, James Cook University, Singapore. E-mail: \\ kannaiah.desti@jcu.edu.au
}

Received: July 31, 2014

doi:10.5539/ijef.v6n11p9

\begin{abstract}
Purpose: In recent years, numerous researches have been conducted on Foreign Direct Investment (FDI) from various perspectives. From a survey on FDI literatures of infrastructure, construction, and service sectors perspective, there are some studies based on the FDI in retailing in single and multi brand made by scholars. However, the perception of unemployed youth on impact of FDI in retailing about employment opportunities in India is yet to be explored. This article is therefore timely and fills the gap in FDI in retailing literature. In a nutshell, the existing organized retailers show a turnover in the range of $\$ 15$ billion to $\$ 18$ billion, leading to the creation of about one million direct and indirect jobs. This implies that Foreign Direct Investment (FDI) retailers need to generate $\$ 60$ billion of turnover in India; it contributes about $14 \%$ to India's gross domestic product (GDP) and is growing at the rate of $15 \%$. The retail sector would guess that in three years it would be a Herculean achievement if FDI leads to the creation of even 0.3 to 0.4 million net additional jobs. In India the pay scales for organized retail shopping mall employees are getting nearly a monthly salary of Rs.5,750 to Rs.6,250 compared to others unorganized retail shopping mall employees, they get a monthly salary of Rs.4,000 to Rs.4,500. It is very interesting to note that the multi-brand retail FDI policy in other countries like China approved 100\% limit that reflects employment opportunities rose from 28 million to 54 million from 1992 to 2001. Based on the above backdrop, an attempt has been made in this paper to study the impact of FDI in retailing with the perception of unemployed youth on employment opportunities in India.
\end{abstract}

Design/Methodology/Approach: Primary data using convenient sampling through questionnaire and interview method as well as secondary data from wide range of literature and various journal publications had been utilized. Frequency distribution, percentage analysis and one way ANOVA were used to test the objectives of the study. In order to test the reliability of the scale, the researcher applied Cronbach's Alpha (CFA) to measure the internal consistency of the variables.

Findings: The findings of the study on impact of FDI in retailing emphasized that the educated youth will get more good and decent employment opportunities in India.

Originality/Value: Impact of FDI in retailing: An empirical analysis on perception of unemployed youth on employment opportunities in India is the original work of the authors.

Keywords: foreign direct investment, retailing, employment opportunities

\section{Foreign Direct Investment: An Overview}

Liberalization of economy has opened a new outlook for the development of FDI in the Indian perspective. The introduction of foreign capital by the investors has been successful in bridging over the gap between requirement of retailers and retail sector. The merit is that customers of almost all branded categories appear satisfied with the quality of services made available to them. A paramount priority to the changing expectations of customers and an equivalent tailoring of financing inputs in tune with the changing business environment have awfully been helpful in increasing the market share of the investors. A transcendental priority to creativity while developing the financial resources has considerably helped them in sensitizing the impulse of prospects. According to A. T. Kearney (2011), the well known International Management Consultancy, recently ranked India as globally, the 'second most attractive retail destination' from among thirty emergent markets. It reported that the Indian retail 
sector accounts for $22 \%$ of the country's Gross Domestic Product (GDP) and contributes to $8 \%$ of the total employment. Thus, the retail industry in India is currently growing in a fast pace and is expected to go up to US $\$ 833$ billion in 2013. It is further expected to reach US $\$ 1.3$ trillion by the year 2018 at a compounded annual growth rate (CAGR) of $10 \%$. Odisha emerged as the top destination for FDI in 2011-2012, accounting for $27 \%$ of the value of all investments in India. The total value of the investments amounted to nearly Rs.50,000 crore. Andhra Pradesh was ranked second, with FDI proposals of about Rs.34,000 crore. The state accounted for about $19 \%$ of the value of all investment proposals. Gujarat, Chhattisgarh and Maharashtra wee ranked third, fourth and fifth respectively. The Associated Chambers of Commerce and Industry ranked Karnataka the fifth among Indian states in terms of attracting FDI proposals in 2011-2012. The total value of the 48 FDI proposals in the state amounted to Rs.14,000 crore, which was $8 \%$ of the value of all the proposals for FDI in India in 2011-2012. It was also reported that the retail sector will create 50,000 jobs in the next few years (Business Standard, August $28,2012)$. Given these developments the FDI is poised for significant growth in the country. Keeping the above backdrop, present study seeks to identify the perception of the unemployed youth about employment opportunities on FDI in retailing in India.

\subsection{Foreign Direct Investment: The Concept and Importance}

FDI refers to an investment in a foreign country, where the investor retains control over the investment (Sodersten, 1979). It also defines as a transfer of package of resources across the countries and that includes capital, technology, management and marketing expertise (Odozo, 1995). FDI is the investment in a foreign country through the acquisition of a local company or the establishment there of an operation on a new (Greenfield) site. To put in simple words, FDI refers to capital inflows from abroad that is invested in or to enhance the production capacity of the economy. According to the International Monetary Fund (IMF), FDI refers to an investment made to acquire lasting or long-term interest in enterprises operating outside of the economy of the investor. The important issue of economic prosperity is always linked to massive inflows of FDI into a nation. It provides impetus for accelerating economic development for a country (Yusop \& Keong, 2002). Its contribution to economic growth is both direct and indirect (Zebregs, 2002). In the developing countries, it has an important role in export promotion (Cheng \& Zhao, 1995). FDI critically depends upon its motive. If the motive is to tap export markets by taking advantage of the country's comparative advantage then it certainly contributes export growth (Lardy, 1994).

\subsection{FDI in Indian Retailing}

The policy of the Central Government till 1997 had been very cautious about FDI in retail. FDI in retail was virtually kept at bay. Though the government has felt the need for more investment in retailing it is still cautious. According to Dr. Ajay K. Dua, Secretary, Department of Industrial Policy and Promotion (DIPP), Ministry of Commerce and Industry, Government of India, "The Centre's decision on allowing FDI in the retail sector - if and when such a decision is taken would be cautious, gradual and calibrated". FDI in the retail sector kick-started and Government cleared the first proposal for up to 51\% in retail trade in February, 2006. This proposal was of setting up a single brand retail store with FDI by Haryana-based Company - Moja Shoes Private Ltd. This proposal was among the total of 12 FDI proposals approved by the Finance Minister, involving FDI worth Rs.371.84 crore in various sectors (Ganesan, 2007).

\subsection{Retail Industry and Employment Generation}

The retail sector can generate huge employment opportunities. It can also lead to job-led economic growth. In most major economies, 'services' form the largest sector for creating employment. US alone have over $12 \%$ of its employable workforce engaged in the retail sector. The Planning Commission of India has identified retail is prospective employment generator, which employees nearly 21 million people, according for roughly $6.7 \%$ of the total employment. However, employment in organized retailing is still very low, because of the small share of organized retail business in the total Indian retail trade. The share of organized retailing in India is $4 \%$. A modern retail/retail services sector has the potential of creating over 2 million new (direct) jobs within the next 6 years in the country (assuming only $8-10 \%$ share of organized retailing) as observed by (Arvind, 2006). Retail can also provide many new jobs in the BPO/IT sector in India (Maruthamuthu, 2007).

\subsection{Pay Bonanza in Organized Retail}

It is inferred from table 1 that the Pay scales for organized retail shopping mall employees are getting a monthly salary of nearly Rs.5,750 to Rs.6250 compared to other unorganized retail shopping mall employees, who get a monthly salary of Rs.4,000 to Rs.4,500. This shows that the organized retail shops are giving more salary compared to other unorganized kirana shops in India as shown in Table 1. 
Table 1. Pay scales

\begin{tabular}{lc}
\hline Nature of job & Salary per month (in Rs.) \\
\hline BPO/back office & 7,000 to 7,500 \\
Driver & 6,500 to 7,000 \\
Organized manufacturing & 6,000 to 6,500 \\
Organized retail & $\mathbf{5 , 7 5 0}$ to $\mathbf{6 , 2 5 0}$ \\
Unorganized retail & 4,000 to 4,500 \\
Shop floor at unorganized factory & 4,000 to 4,500 \\
Peon / delivery boy & 3,100 to 3,400 \\
Security & 2,800 to 3,000 \\
Community services & 2,600 to 2,800 \\
\hline
\end{tabular}

Source: Apama Kalra, Business Standard, $3^{\text {rd }}$ December, 2011.

\subsection{Share of Organized Retail in India}

The Indian retail sector is highly fragmented with 94.5 percent of its business being run by the unorganized retailers. The organized retail however is at a very budding stage. The sector is the largest source of employment after agriculture, and has deep penetration into rural India generating more than 14 percent of India's GDP. The following figure 1 clearly shows the distribution of retail trade in organized sector and unorganized sector in India and Southeast Asian countries.

\begin{tabular}{lccc}
\hline Country & Total Retail Sales (USS bn) & Share of organized retail (\%) \\
\hline USA & 2,983 & 85 & \\
UK & 475 & 80 & \\
France & 436 & 80 & \\
Germany & 421 & 80 & \\
Japan & 1,182 & 66 & \\
Malaysia & 34 & 55 & \\
Thailand & 68 & 40 & \\
Argentina & 53 & 40 & \\
Brazil & 284 & 36 & \\
Philippines & 51 & 33 & \\
Russia & 276 & 30 & \\
Indonesia & 150 & 30 & \\
Czech Republic & 34 & 30 & \\
Hungary & 24 & 22 & \\
Vietnam & 26 & 20 & \\
China & 785 & 20 & \\
Poland & 120 & 15 & \\
South Korea & 201 & 4 & \\
India & 322 & 1 & \\
Pakistan & 67 & \\
\hline
\end{tabular}

Figure 1. Where India stands: share of organized retail in India compare to other countries

Source: Apama Kalra, Business Standard, $3^{\text {rd }}$ December 2011.

From the above figure 1, it is revealed that organized retail in India is infancy stage and it is very low even in comparison with other Asian developing economies like China, Thailand, South Korea and Philippines all of whom have figures hovering around the 20-25 percent mark.

\subsection{FDI Policy at Global Level}

It is very interesting to note that the multi-brand retail FDI policy in other countries like China approved $100 \%$ limit which denotes that the employment opportunities rose from 28 million to 54 million from 1992 to 2001. However, in Thailand 100\% FDI in multi-brand had adverse effect on the local retailers are given in table 2. 
Table 2. FDI policy at global level



Source: Joeanna Rebello Fernandes, Sunday Times of India, $4^{\text {th }}$ December, 2011.

\subsection{FDI in Retail-Foreign Chains}

Wal-Mart Stores Inc. It has a cash and carry operation with Indian partner Bharti Enterprises, the parent of leading mobile provider Bharti Airtel, operates 14 stores.

Tesco. Britain's largest retailer has a tie-up with Trent's Star Bazaar hypermarket chain. Tesco is also looking forward to enter the wholesale market through the tie up.

Metro AG. Germany's Metro AG operates eight wholesale stores.

Carrefour. It has two cash-and-carry stores, on in Delhi, one in Jaipur. The world's No.2 retailer seeking a local partner to enter the hyper or supermarket (Apama, 2011).

\section{Review of Literature}

FDI in retailing refers to a retail store with a foreign investment that can sell goods/brands under one roof. The review of literature made for this study shows that the major impact of FDI in retailing will be felt by the educated unemployed youth in India, and it will also have an impact on the creation of employment opportunities and in the area of use of technology. To justify the need of present study, following literature has been reviewed.

Bhagwati (1978) analyzed the impact of FDI on international trade. He concluded that countries that actively pursue export led growth strategy can reap enormous benefits from FDI. De Mello (1999) stated that many of the East Asian tigers such as China, South Korea, Malaysia and Singapore benefitted from investment abroad. Gorg and Greenaway (2004) in his study of economic theory suggested that FDI is an engine of economic growth in developing countries. Jitndra (2005) pointed that the Indian retail market is not only promising, but in terms of potential, India was poised to be the next China. Opening up of the sector to FDI in a 'measured' way will lead to new economic opportunities and more employment generation. Botric and Skuflic (2006) identified the reason as the FDI inflows stimulate capital accumulation by adding to domestic savings and raising the recipient economy's efficiency, for instance, through improving resource allocation, job creation, increasing industrialization, instilling competition, scale economies, imitation, technology spillovers, improving human capital, deepening domestic financial markets and reducing local capital costs. Rudra (2006) analyzed the FDI along with portfolio investment helped the host countries in supplementing its domestic capital resources, catering modern technology, improving worker and managerial skills, boasting experts and thus, achieving the international competitiveness of the country. Editor (2007) identified that India has 100 million people in the age group of 20-24, young workers with employable skills will remain in short supply. There is a real need of professional education and training to the upcoming youth. Ganesan (2007) identified the factors like government policy, infrastructure development, GDP growth and employment generation and job creation in several new sunrise industries resulting in greater purchasing power. FDI facilitates manpower and skill development through retail training. This also opens up a scope for greater managerial talent inflow from other countries. People Democracy (2007) in his study have identified that the retail is the largest sector in India after agriculture, accounting for over $10 \%$ of the country's GDP and employs over 4 crore people. Within this, retail is 
certainly going to create employment opportunities for the youth. Setting up of retail outlets by big retailers from all over the world in different parts of the country will help in removing regional inequalities by providing avenues for the employment. Valsamma (2007) argued that our Small Scale Industry (SSI) sector could be trained and appraised of quality techniques and standards and thus their products would find entry into the international markets. With proper policy measures to develop and promote this priority sector, these units would get a boost with the advent of international retailers, resulting in employment, exports and overall economic development. Tamana (2008) discussed that India will benefit a great deal if the government can encourage organized retailing through proactive policy measures, including opening up of FDI for multi-brand retailing in a phased manner. The author argues that though the growth of organized retailing may lead to some unemployment and displacement in the short term, the long term benefits will far outweigh the possible negative consequences. Khandelwal (2010) studied that large investment in infrastructure would lead to a rise in farm productivity, manufacturing and food processing as well as cold storage facilities. This would cut down wastages and spur growth in employment, exports and GDP. According to the Department of Industrial Policy and Promotion (DIPP, 2010) discussion paper on FDI in multi brand, more than $2 / 3^{\text {rd }}$ of the total employment, in the broad category of trade, hotels and restaurants, is in the retail sector. There will be huge job opportunities in the country (in crores) as there will be opening of malls and store houses. Supriya Biswas (2012) analyzed the impact of the FDI is that it would generate a decent amount of employment as more and more entrepreneurs would be coming forward to invest and taste the new generation in retail marketing. Dilip James (2011) reviewed that it would be a herculean achievement if FDI leads to the creation of even 0.3 to 0.4 million net additional jobs. At the same time, contrary to the view of those opposing FDI, it is also unlikely that there will be large-scale extinction of the kiranas or small stores. Sainath (2011) stated that here is the wonderful thing about the FDI in retail debate; never have struggling Indian farmers found so many champions. They have been crawling out of the woodwork. Faizur (2011) pointed out that the FDI is an instrument of corporatocracy through which it seeks to enslave us. Chandrasekhar (2011) expressed that with deep pockets and international sourcing capabilities, global retail chains will out compete domestic players, displace jobs, and undermine livelihoods. Rawat (2011) said that, "It will send a very negative message to foreign investors". FDI in multi-brand retail could have created over 10 million jobs in three years, curbed wastage of farm products and benefited farmers. Limba (2011) investigated that FDI generates considerable benefits. These include employment generation, the acquisition of new technology and knowledge, human capital development, contribution to international trade integration, creation of a more competitive business environment and enhanced local enterprise development. Bisaria (2012) stated that the entry of modern retailers will expand the market, creating large amount of additional jobs in retail. The job opportunities will vary from ordinary workers to specialized officers. Jayadev et al. (2012) in their study they argued that the multinationals settings up shop in retail would help creates jobs and modernizes agriculture and marketing in the country and it is estimated that in the organized sector there will be an employment opportunity of 10 million jobs. Popli and Manish (2012) viewed that the retail sector of India is a robust pillar of the economy which employs $6 \%$ of the national's workforce and contributes $13 \%$ to GDP. As a result of FDI in retail one million (1 crore) employment will be created in three years. Goel and Ritu (2013) expressed that FDI is a profiler for the economic development of any country like India. FDI helps transfer and upgrade technology; improves skills and managerial capabilities; provides competitive edge to country's exports improves efficiency and quality of services and goods; and helps create additional jobs. The above literature shows the important contribution of FDI in retailing. It is also evident from the above literature that FDI in retailing create more employment opportunities for unemployed youth in India. In light of above literature, the present study attempts to identify the perception of educated unemployed youth on FDI in retailing about the employment opportunities in India.

\subsection{Statement of the Problems}

Retailing is a kind of business activity, which offers products or services in small quantities to ultimate consumers, at a place where consumers prefer to buy. Especially, in countries like India, till date, the unorganized retailers play a predominant role in offering products or services of different products or service mix at the convenient location, i,e., Kirana stores or Apana Bazar, with effective selling and buyer's retention strategies. There is widespread skepticism about the entry of foreign players include Wal-Mart, Home Depot, Kroger, Costco and Target from US, Carrefour and Tesco from France, Metro, Schwarz Group and Aldi Einkauf from Germany in our retail market. It is feared that the unorganized sector will be thrown out of business if the country opens up FDI for multi brand stores or allows 100 percent FDI in retail business. The following are the main aspects of the fright on the earlier studies.

Employment generation, which is expected from FDI in multi brand retail, shall be nullified as many retailers 
will lose their business owing to tough competition. India has 35 towns, each with a population of over one million. If Wal-Mart were to open a store in each of these cities, and they reach the average Wal-Mart performance per store, we are looking at a turnover of over Rs.80,330 mn with only 10,195 employees. Extrapolating this with the average tread in India, it would mean displacing about 4,32,000 persons if large FDI driven retailers were to take 20 percent of the retail trade, as the now somewhat hard-pressed Hindustan Lever Limited anxiously an tic pates, this would mean a turnover of Rs.800 billion. This would mean an employment of just 43,540 people, displacing nearly a million people employed in the unemployed sector (Guruswamy et al., 2005). The indigenous units manufacturing and processing variety of products with local resources would suffer, as they may not have widespread market for their wares. This condition would affect the volume of employment in the unorganized sector (Ganesan, 2007). It is true that some jobs are being created for the English-speaking graduates in these retail outlets. But the jobs being created are much less than the number of people displaced from their retail business. Wal-Mart had a turnover of $\$ 345$ billion in its fiscal year ending January 31, 2007 , employing only 1.3 million people in the US. Considering the fact that in the fiscal year ending $2006,80 \%$ of its sales came from the US, it can be assumed that approximately $\$ 280$ billion is generated from 4000 stores across the US, employing 1.3 million. While almost the same amount for sales revenue is generated by 13 million stores employing roughly 80 million populations. So, the contention that the process of organized retail creates jobs is not true (Krishna, 2007). Retailing as an industry in India has still a long way to go. To become a truly flourishing industry, retailing needs to cross the various hurdles like lack of trained work force and low skill level for retaining management (Maruthamuthu, 2007). Indian retailers have yet to consolidate their position. The existing retailing scenario is characterized by the presence of a large number of fragmented family owned businesses, who would not be able to survive the competition form global players. The examples of South East Asian countries show that after allowing FDI, the domestic retailers were marginalized and this led to unemployment. The opening up of the retail sector would affect the sales in the unorganized sector. As a result the employment it provides would be affected. Also, by reducing the number of intermediaries, organized retailing will lead to some job displacement. It is said that FDI would provide employment opportunities. But, the fact is that they cannot provide employment opportunities to semi-illiterate people. Though they can provide employment opportunities like drivers, watchman etc. but this argument gets more attention because in India semi-illiterate people in quite large number (Mamta, 2012). More than 20\% of Indians in the 15-24 age groups were jobless and seeking work. In absolute terms, this army of unemployed youth is staggeringly huge - around 4.7 crore, of which 2.6 crore were men and 2.1 crore women (Subodh, 2014). Nearly 160 million women in India, $88 \%$ of whom are of working age, that is between 15 to 59 years, just remain at home doing "household duties" (Subodh, 2014). From the various problems discussed so far it is obvious that there is some fear psychosis among kiranas because they would not find a place to sell their products in local market and there by the workers who work in Kiranas will lose their jobs and also the above research studies individually focus on FDI in retailing on prospects, challenges, opportunities and threats in single and multi brand in India in general and no serious attempts seem to have been made to combine all these aspects that too on the employment opportunities for unemployed youth in India. No study seems to concentrate on the perception of unemployed youth on Impact of FDI in retailing. Besides, no reference seems to have been made as far as the Impact of FDI in retailing. Hence, the authors have undertaken the present study entitled "Impact of FDI in Retailing: An Empirical Analysis on Perception of Unemployed Youth on Employment Opportunities in India".

\subsection{Research Question}

In this study, the researchers are seeking to answer the following question:

Will FDI in retailing create more employment opportunities for educated unemployed youth in India or not?

\subsection{Objectives of the Study}

1). To study the demographic profile of the respondents

2). To identify the perception and impact of FDI in retailing to create more employment opportunities for unemployed youth in India.

\subsection{Research Hypotheses}

In order to conduct this investigation and to answer the proposed question and considering the results achieved by the previous studies, the following hypotheses are formulated:

Ho: (Null hypotheses) There is no significant relationship between education and impact of FDI in retailing will create more employment opportunities for unemployed youth in India.

H1: (Alternative hypotheses) There is significant relationship between education and impact of FDI in retailing 
will create more employment opportunities for unemployed youth in India.

\section{Methodology of the Study}

The research attempt is empirical in nature. The present study is based on primary as well as secondary data. The sources of primary data were collected through a well framed and structured questionnaire. The secondary data were collected from published sources like journals, magazines, internet, news papers, books, annual reports of FDI in retailing and earlier studies. The sample for this study consisted of respondents from five states from South India namely Chittor city from Andhra State, Bangalore city from Karnataka State, Kollam city from Kerala State, Pondicherry city form Pondicherry State and Vellore city from Tamil Nadu State. All the respondents were unemployed youth. Convenience sampling was used to collect the samples. A total of 625 samples were issued and only 586 samples were collected out of which only 542 samples were taken for analysis and remaining 44 samples were not taken into account due to incompleteness of the questionnaire. Before conducting field survey, the questionnaire was pre-tested and a few modifications were made. A final version of structured questionnaire with two sections was developed to find out viz., 1. Demographic profile and 2. The impact of FDI in retailing about the perception of unemployed youth on employment opportunities in India. The questionnaire of the study consisted of multiple choices and Likert's five point scale from 1-Strongly Disagree to 5-Strongly Agree (Appendix A). The SPSS package 20 was used for analysis. Statistical tools like percentage analysis, frequency distribution and one way ANOVA were applied.

\subsection{Test of Reliability}

The current study has used Cronbach's alpha, which is the most widely used measure for testing the reliability. It requires only a single test administration and is easy to compute when using a correlation matrix. Cronbach's alpha is expressed as $\alpha=\mathrm{Np} /[1+\mathrm{p}(\mathrm{N}-1)]$ (Carmines \& Zeller, 1979), where $\mathrm{N}$ is the number of statements and $\mathrm{p}$ is the mean inter-item correlation. The dataset used for the study had a Cronbach's alpha of 0.990. As per Hair et al. (1998), the generally agreed upon lower limit is 0.70 , while (Carmines \& Zeller, 1979) believe that the alpha should not be below 0.80 for widely used scales. Considering these guidelines, it would be appropriate to conclude that the data used for one way ANOVA exhibit a very good reliability.

\subsection{Limitations of the Study}

The major limitation of this study is that the findings may not be universally acceptable as it is research paper. The perceptions of the same respondents may differ at different points of time. In case, if more number of sample respondents had been collected for the study, the results might have differed. Another limitation of this study is that the researcher does not consider the opinion of the foreign direct investors, producers, retailers and consumers, who are the major stakeholders in single or multi brand retailing. The study area is restricted only in South India and it does not cover the whole India. The study period is limited to six months only i.e, from $1^{\text {st }}$ January, 2014 to $31^{\text {st }}$ May, 2014.

\section{Analysis and Findings}

\subsection{Percentage Analysis}

The data pertaining to demographic profile of the respondents were given in table 3 .

Table 3. Demographic profile

\begin{tabular}{cccc}
\hline Variable & Category & Frequency & Percentage \\
\hline Gender & Male & 289 & 53 \\
& Female & 253 & 47 \\
& Total & $\mathbf{5 4 2}$ & $\mathbf{1 0 0}$ \\
Nativity & Rural & 233 & 43 \\
& Urban & 309 & 57 \\
& Total & $\mathbf{5 4 2}$ & $\mathbf{1 0 0}$ \\
State & Andhra & 120 & 22 \\
& Karnataka & 94 & 17 \\
& Kerala & 105 & 20 \\
& Pondicherry & 99 & 18 \\
& Tamil Nadu & 124 & 23 \\
& Total & $\mathbf{5 4 2}$ & $\mathbf{1 0 0}$ \\
& B.Com & 105 & 19 \\
\hline \multirow{5}{*}{ Education } & & &
\end{tabular}




\begin{tabular}{ccc}
\hline BBA & 39 & 07 \\
B.Sc & 42 & 08 \\
BCA & 56 & 10 \\
M.Com & 92 & 17 \\
MBA & 93 & 18 \\
MS (SE) & 67 & 12 \\
MCA & 48 & 09 \\
Total & $\mathbf{5 4 2}$ & $\mathbf{1 0 0}$ \\
\hline
\end{tabular}

Source: Primary data.

\subsection{Inference}

From table 3 it is inferred that, majority (53\%) of the respondents belong to male category and $47 \%$ respondents belong to female category. With regard to native, 309 out of 542 respondents belong to urban area and 233 respondents out of 542 belong to rural area. South India consists of 5 states namely, Andhra, Karnataka, Kerala, Pondicherry and Tamil Nadu. Out of these states 124 (majority) respondents were from Tamil Nadu and 120 respondents were from Andhra. Educational qualification is the base for any decision making and it is also very interesting to hear from this study that 105 (maximum) respondents were educated B.Com and 93 respondents were educated MBA. Therefore, it is very clear to say that all the respondents having either arts or science degree.

\subsection{One Way ANOVA - Testing of Hypotheses}

The data pertaining to education and impact of FDI in retailing the perception of unemployed youth respondents with respect to employment opportunities in India were given in table 4.

Table 4. One way ANOVA

\begin{tabular}{|c|c|c|c|c|c|c|}
\hline Variables & & Sum of squares & Df & Mean square & $\mathbf{F}$ & Sig \\
\hline \multirow{3}{*}{$\begin{array}{l}\text { Impact of FDI in retailing create } \\
\text { more employment opportunities in } \\
\text { services, manufacturing and } \\
\text { agricultural sector for the youth }\end{array}$} & Between Groups & 1103.872 & 7 & 157.696 & 1652.359 & $.000^{*}$ \\
\hline & Within Groups & 50.963 & 534 & .095 & & \\
\hline & Total & 1154.836 & 541 & & & \\
\hline \multirow{3}{*}{$\begin{array}{l}\text { Improvement in the quality of } \\
\text { employment }\end{array}$} & Between Groups & 1030.187 & 7 & 147.170 & 1290.801 & $.000^{*}$ \\
\hline & Within Groups & 60.884 & 534 & .114 & & \\
\hline & Total & 1091.070 & 541 & & & \\
\hline \multirow{3}{*}{$\begin{array}{l}\text { Removing regional inequalities by } \\
\text { providing avenues for the } \\
\text { employment }\end{array}$} & Between Groups & 1127.244 & 7 & 161.035 & 1602.168 & $.000^{*}$ \\
\hline & Within Groups & 53.673 & 534 & .101 & & \\
\hline & Total & 1180.917 & 541 & & & \\
\hline \multirow{3}{*}{$\begin{array}{l}\text { Manpower and skill development } \\
\text { helps to introduce more skilled } \\
\text { labours }\end{array}$} & Between Groups & 1120.568 & 7 & 160.081 & 1163.508 & $.000^{*}$ \\
\hline & Within Groups & 73.470 & 534 & .138 & & \\
\hline & Total & 1194.039 & 541 & & & \\
\hline \multirow{3}{*}{$\begin{array}{l}\text { Retail training increase the inflow } \\
\text { of talented managers from other } \\
\text { countries }\end{array}$} & Between Groups & 684.441 & 7 & 97.777 & 834.470 & $.000^{*}$ \\
\hline & Within Groups & 62.570 & 534 & .117 & & \\
\hline & Total & 747.011 & 541 & & & \\
\hline \multirow{3}{*}{$\begin{array}{l}\text { Increase number of courses in } \\
\text { retailing }\end{array}$} & Between Groups & 995.654 & 7 & & 1338.865 & $.000^{*}$ \\
\hline & Within Groups & 56.730 & 534 & 142.236 & & \\
\hline & Total & 1052.384 & 541 & .106 & & \\
\hline \multirow{3}{*}{$\begin{array}{l}\text { More institution offer business / } \\
\text { commerce education }\end{array}$} & Between Groups & 885.921 & 7 & 126.560 & 1040.309 & $.000^{*}$ \\
\hline & Within Groups & 64.964 & 534 & .122 & & \\
\hline & Total & 950.886 & 541 & & & \\
\hline
\end{tabular}

Source: Primary data; $*$ Significance at $5 \%$ level.

\section{Findings}

1). Table 4 reveals that there is a statistical significant relationship in the perception of unemployed men and women respondents with respect to their opinion on the impact of FDI in retailing to create more employment 
opportunities for unemployed youth in India, because the calculated value of one way ANOVA is 0.000 , which is less than the hypothetical value $(\alpha=0.05)$ at $5 \%$ level of significance. Hence, the null hypothesis (Ho) not accepted.

2). It is also very interesting to see from the above table that all remaining variables like improvement in the quality of employment, removing regional inequalities by providing avenues for the employment, manpower and skill development helps to introduce more skilled labours, retail training increase the inflow of talented managers from other countries, increase number of courses in retailing and more institution offer business / commerce education also significant relationship with the impact of FDI in retailing in India.

\section{Conclusion}

The retailers in organized and unorganized sector are adopting new strategies to enhance their market share. The present study was conducted with the purpose of identifying the impact of FDI in retailing with the perception of unemployed youth on employment opportunities in India. To conclude, FDI in retail will help integrate the Indian economy with the global economy. It will also help increase the experience in organized retailing sector and the availability of quality human resources at low costs. FDI in retail would reduce the intermediate costs and the costs of production and impose setting up of integrated supply chains that would minimize wastage, give producers a better price and will be beneficial to producers/manufactures and consumers. However, it can be said that the advantages of allowing FDI in the retail sector evidently outweigh the constraints attached to it and the same can be deduced from the examples of successful experiments in countries like Thailand and China, where the issue of allowing FDI in retail sector was first met with incessant protests, but later turned out to be one of the most promising political and economical decisions of their governments and led not only to the commendable rise in the level of employment but also led the enormous development of their country's GDP. Hence, from the above research study it is evident that FDI in retail will certainly create more job opportunities for unemployed for those youth who are skilled and trained. However, there is a lot workforce in India, who is unskilled. Skilled and trained persons have never been the problem for our policy makers. Therefore, FDI in retailing is need of the hour for creation of more jobs for unemployed youth in India, expansion of existing manufacturing industries, development of the new one and it would also help India in becoming 'developed country'.

\section{Suggestion}

FDI in retail is a very crucial step that is been undertaken to ensure further growth in the Retail Sector of India. This will transform the retail environment of the country in a significant way. As per Standard Chartered Research, 'The world has entered in its third super cycle characterized by Industrialization, Urbanization and International trade'. FDI in Indian Retail not only prove fruitful for the economy as a whole but it will also integrate this sector with the global retail market. The results of FDI in China are a case for example here. In Chinese market development of 100\% FDI was done in 2004, today its retail sector is the second largest in value in the world. Further FDI in retail in India may also help bring in technical knowhow to set up efficient supply chains which could act as models of development. In a true potential scenario, opening up of FDI can increase organized retail market size to $\$ 260$ billion by 2020 . Therefore, FDI in retail is not only necessary for creation of more jobs and thereby providing more employment opportunities to unemployed youth in India, expansion of existing manufacturing industries, development of the new one but it will also definitely give a boost to the organized retail sector of India, which positively impacts several stakeholders, including producers, workers, employees, farmers, consumers, the Government, the overall economy in real sense. Finally, creating employment opportunities for rural youth is the main concern of our government since independence. FDI in retail can provide employment opportunities to these rural youth. It is upon the government agencies and various organizations to frame certain policies with the help of which these rural youth can be encouraged and trained as per the requirement of these big retailers.

\section{Managerial Implications}

Impact of FDI in retailing in India will bring a new set of challenges with reference to managing diversified groups of people at work. In addition, a number of job opportunities will be created due to the adoption of modern technology in the areas of processing, grading, handling, packaging, bar coding, transportation of goods etc. So, recruitment policies and strategies need to be revised. Customer satisfaction would have to be given utmost care since the local brands will be competing with the international brands. Thus, all these would require proper planning and management by the organizations in the future to face international competition in India. 


\section{References}

Apama, K. (2011). Organized Retail: Stopping a Juggernaut? (3rd ed., p. 2). Business Standard.

Arvind, S. (2006). Indian Retail Report 2005. Highlights IMAGES KSA Technopark.

Bhagwati, J. N. (1978). Anatomy and Consequences of Exchange Control Regime. Studies in International Economies Relations, 10. New York. Retrieved from Http://ideas-repec.org/b/nbr/nberbk/bhag78-1.html

Bisaria, G. (2012). Foreign Direct Investment in Retail in India. International Journal of Engineering and Management Research, 2(1), 31-36.

Botric, V., \& Skuflic, L. (2006). Main Determinants of Foreign Direct Investment in the Southeast European Countries. Transition Studies Review, 13(2), 359-377. http://dx.doi.org/10.1007/s11300-006-0110-3

Business Standard Report. (2012, August 28). Gujarat 3rd Most Favorite Destination for FDI, says Assocham Study. Retrieved from http://www.business-standard.com

Carmines, E., \& Zeller, R. (1979). Reliability and Validity Assessment. Sage University Paper, Sage Publications, Beverly Hills. http://dx.doi.org/10.4135/9781412985642

Chandrasekhar, C. P. (2011). The Retail Counter-Revolution (p. 10). The Hind.

Cheng, L. K., \& Zhao, H. (1995). Geographical Pattern of Foreign Direct Investment in China: Location, Factor Endowments and Policy Incentives. Department of Economics, Hong Kong University of Science and Technology, Hong Kong, February.

De Mello, J. L. R. (1999). Foreign Direct Investment-led Growth: Evidence from time Series and Panel Data. Oxford Economic Papers, 51(1), 133-151. http://dx.doi.org/10.1093/oep/51.1.133

Dilip, J. (2011). No Retail Therapy in Sight (p. 14). Business Standard.

DIPP. (2010). FDI in Multi Brand Retail Trading. Discussion Paper.

Editor. (2007). India Retail: A Big Story. The Economic Challenger, 35(9), 3-6.

Faizur, R. (2011). It May End Up as Foreign Direct Interference (p. 11). The Hindu.

Ganesan. (2007). FDI in Retail Trade in India. The Economic Challenger, 35(9), 40-45.

Goel, M. M., \& Ritu, K. W. (2013). Growth and Performance of FDI in Indian Economy: An Analysis. View Point, 4(2), 3-12.

Gorg, H., \& Greenaway, D. (2004). Much Ado about Nothing? Do Domestic Firms Really Benefit from FDI? World Bank Economic Observer, 19(2), 171-197. http://dx.doi.org/10.1093/wbro/lkh019

Guruswamy, S. M., \& Thomas. (2005). FDI in India's Retail Sector: More Bad Than Good. CPAS Centre for Policy Alternatives, 94.

Hair, J., Anderson, R., Tatham, R., \& Black, W. (1998). Multivariate Data Analysis. Prentice-Hall International Edition. New Jersey.

Jayadev, S., Bino, J., \& Sijusebastian. (2012). Influence of FDI on Retail Sector. Yojana, 21-28.

Jitendra, S. (2005). Organized Retail Sector: Poised for Growth. Fortune India.

Joeanna, R. F. (2011). Why the Kiranawala Has a Charm of His Own? Sunday Times of India.

Kearney. (2011). Retail Global Expansion: A Portfolio of Opportunities-The 2011. A.T. Kearney Global Retail Development Index. Retrieved from http://www.atkearney.com

Khandelwal, P. (2010). Is FDI in Retail Good Idea. Business Standard.

Krishna, K. A., \& Arun, K. R. (2007). FDI in Retail: Effect on the Socioeconomic Balance. Marketing Mastermind, $\operatorname{VII}(8), 37-41$.

Lardy, N. (1994). China in the World Economy. Institute for International Economics.

Limba, G. (2011). Causality Between Foreign Direct Investment (FDI) and Economic Growth (GDP in India During 1991-1992 to 2009-2010. International Journal of Applied Business and Economic Research, 9(2), $167-176$.

Mamta, J., \& Meenal, L. S. (2012). FDI in Multi Brand Retail: Is It The Need of the Hour? International Journal of Multidisciplinary Research, 2(6), 108-131.

Maruthamuthu. (2007). Retail Industry in India-A Review. The Economic Challenger, 36(9), 25-30. 
Odozi, V. A. (1995). An Overview of Foreign Investment in Nigeria: 1960-1995. Occasional Paper, CBN Research Development, Nigeria.

People Democracy. (2007). National Policy on Regulation of Organized Sector in Retail Trade: A Proposal.

Popli, G. S., \& Manish, M. (2012). Prospects of FDI in Retail Sector: An In-depth Study from Indian Perspective. Productivity, 53(2), 113-122.

Rawat. (2011). Describing the Volte face as a Case of Missed Opportunity. The Financial Express, XXXII(183), 1.

Rudra, P. P. (2006). FDI in the Globalization Era: Chinese and Indian Experiences. Journal of Social and Management Sciences, XXXIV(4), 323-343.

Sainath, P. (2011). FDI in Retail-UPA "Retired Hurt". The Hindu.

Sodersten, B. O. (1979). International Economics. Macmillan Press.

Supriya, B. (2012). FDI Inflow in Indian Retailing-Growth Model and Challenges. Indian Journal of Marketing, $40(12), 19-28$.

Surojit, G. (2011). War For the Mart. Sunday Times of India.

Subodh, V. (2014). Over 20\% of Young Indians are Unemployed. The Times of India, 7(157), 1.

Subodh, V. (2014). 16cr Jobless Women from India's Great Invisible Force. The Times of India.

Tamana, A. (2008). Organized Retailing in India: Need of the Hour. Marketing Mastermind, VII(3), 28-30.

Valsamma, A. (2007). FDI in Retail Business-New Opportunities. The Economic Challenger, 35(9), 46-48.

Yusop, Z., \& Keong, C. C. (2002). Foreign Direct Investment in the Malaysian Manufacturing Sector. In Azali et al. (Eds.), APEBC Proceedings (Vol. 1, pp. 356-364). Universiti Putra, Malaysia, Serdang.

Zebregs, H. (2002). Foreign Direct Investment and Output Growth. In W. Tseng \& M. Rodlauer (Eds.), China: Competing in the Global Economy. International Monetary Fund, and Washington.

\section{Appendix A.}

Impact of FDI in Retailing: An Empirical Analysis on Perception of Unemployed Youth on Employment Opportunities in India Questionnaire

\section{Personal Information}

1. Name (optional) :

2. Age : 18 to $20(\quad) 21$ to $23(\quad) 24$ to $26(\quad)$

3. Education : B.Com ( ) BBA ( ) B.Sc ( ) BCA ( ) M.Com ( ) MBA ( ) M S(SE) ( ) MCA )

4. Gender: Male ( ) Female ( )

5. Native : Rural ( ) Urban ( )

6. State: Tamil Nadu（） Andhra（） Karnataka（）Kerala（）Pondicherry（）

Please read each statement carefully and decide to what extent it applies to you. Tick the appropriate number as per the table given below.

5. Strongly agree 4. Agree 3. Neither agree nor disagree 2. Disagree 1. Strongly disagree

$\begin{array}{lllll}5 & 4 & 3 & 2 & 1\end{array}$

\section{Employment opportunities for youth}

1. Impact of FDI in retailing create more employment opportunities in service, manufacturing and agriculture sector for the youth ()()()()()

2. Improvement in the quality of employment $($ ) ()()()$($ )

3. Removing regional inequalities by providing avenues for the employment $($ ) ( ) ( ) ( ) ( ) 
4. Manpower and skill development helps to introduce more skilled labours $(\quad)(\quad)(\quad)(\quad)$

5. Retail training increase the inflow of talented managers from other countries $(\quad)()()()()$

6. Increase number of courses in retailing ()()()()$(\quad)$

7. More institution offer business / commerce education $(\quad)()()()()$

\section{Copyrights}

Copyright for this article is retained by the author(s), with first publication rights granted to the journal.

This is an open-access article distributed under the terms and conditions of the Creative Commons Attribution license (http://creativecommons.org/licenses/by/3.0/). 